\title{
Serological Detection of Four Plant Viruses in Cucurbitaceous Crops from Bangladesh
}

\author{
Abdul Mannan AkandA*, Kazunori Tsuno* and Satoshi Wakimoto*
}

\begin{abstract}
In all 21 samples of various cucurbitaceous crops showing virus disease-like symptoms were collected in 1986-87 from different locations of Bangladesh and preserved at $4^{\circ} \mathrm{C}$ after lyophilization or with calcium chloride. These dried samples were used for serological detection of different cucurbit-viruses, viz., cucumber mosaic virus (CMV), papaya ringspot virus (PRSV/WMV 1), watermelon mosaic virus 2 (WMV 2), zucchini yellow mosaic virus (ZYMV), cucumber green mottle mosaic virus (CGMMV) and squash mosaic virus (SqMV) by double antibody sandwich enzyme-linked immunosorbent assay (DAS-ELISA) and dotimmunobinding assay (DIBA) in 1989. Out of the 21 samples tested, two, nine, one and three were found to be positive against the antisera of CMV, PRSV, WWV 2 and SqMV, respectively. None of the samples reacted positively against the antisera of ZYMV and CGMMV. Some samples of bottlegourd, bittergourd, cucumber and pumpkin did not react with any of the antisera used.
\end{abstract}

(Received October 9, 1990)

Key words : cucurbit-virus, dried sample, DAS-ELISA, DIBA, Bangladesh.

\section{INTRODUCTION}

Cucurbitaceous plants include very important crops all over the world ${ }^{9,10,19,29)}$. Among various diseases of cucurbitaceous crops caused by different pathogens such as fungi, bacteria, viruses, nematodes etc., the virus diseases have been given special importance due to non-availability of resistant species, epidemiological hazards and lack of effective control measures ${ }^{13,19}$. Lovisolo $^{19)}$ reported that as many as 50 different viruses have been found to be able to infect cucurbits naturally or experimentally. Among these viruses, such as cucumber mosaic virus (CMV), papaya ringspot virus (PRSV/WMV 1), watermelon mosaic virus 2 (WMV 2), zucchini yellow mosaic virus (ZYMV), cucumber green mottle mosaic virus (CGMMV), squash mosaic virus (SqMV) etc. cause serious damage to the crops throughout the world ${ }^{3,4,11,12,16,17,19,20,22,23,32,33)}$. Most of these viruses have also been reported from different tropical Asian countries including India and Sri Lanka which are two neighbours of Bangladesh ${ }^{12,30,31)}$. So, it is likely to be thought that some of these important viruses may be prevalent on various cucurbitaceous crops in Bangladesh.

In Bangladesh, several species of cucurbits, viz., cucumber (Cucumis sativus), sweetgourd/ summer squash (Cucurbita moschata), bottlegourd (Lagenaria siceraria), whitegourd/waxgourd (Benincasa hispida), pumpkin (Cucurbita maxima), bittergourd/balsam pear (Momordica charantia), spongegourd (Luffa cylindrica) and round cucumber (Cucumis sativus) are cultivated as major vegetable crops ${ }^{25,26}$. Some of them are considered to be very important as they provide year round vegetables in Bangladesh ${ }^{26}$. It is observed that these crops suffer from diseases showing symptoms similar to the virus diseases causing tremendous yield loss every year. However, the virus diseases of crops in Bangladesh remain uninvestigated until now, due to lack

\footnotetext{
* Faculty of Agriculture, Kyushu University, Fukuoka 812, Japan九州大学農学部
} 
of proper facilities and trained manpower ${ }^{1}$. In the present study, the serological detection of viruses infecting various cucurbitaceous crops in Bangladesh was emphasized.

\section{MATERIALS AND METHODS}

Samples. In total 21 samples comprised of nine different species of cucurbitaceous crops were collected from different locations of Bangladesh in 1986-87 (Table 1). The leaves of the plant showing virus disease-like symptoms in the field were collected in small polyethylene bags and immediately processed for drying by lyophilization or with calcium chloride. These dried samples were carried to Japan and stored at $4^{\circ} \mathrm{C}$ until testing in 1989.

Antisera. Polyclonal antisera of CMV-serotype Y (CMV-Y), PRSV-watermelon strain (PRSV-W), PRSV-papaya strain (PRSV-P), WMV 2, ZYMV, CGMMV-yodo strain (CGMMV-Y), CGMMV-watermelon strain (CGMMV-W) and SqMV were used in the experiments. PRSV-W, WMV 2 and ZYMV antisera were provided by Dr. N. Sako, Saga University, Japan. PRSV-P antiserum was generously given by Dr. D. Gonsalves of Cornell University, USA. Antisera of CMV-Y and SqMV were obtained from by Dr. T. Maeda, Okayama University, Japan and CGMMV ( $\mathrm{Y}$ and $\mathrm{W}$ ) antisera were also provided by Dr. M. Kameya, National Agriculture Research Center, Tsukuba, Japan.

Inoculation test. All the 21 cucurbitaceous samples were inoculated separately to the respective host plants and also to some common local lesion hosts several times, following standard inoculation procedures described by Hill ${ }^{15}$. The inoculated plants were maintained in an air-conditioned greenhouse, temperature of which was controlled at $20-25^{\circ} \mathrm{C}$. The buffer used for inoculation was $0.02 \mathrm{M}$ phosphate containing $0.5 \%$ sodium sulfite, $\mathrm{pH}$ 7.2.

Double antibody sandwich enzyme-linked immunosorbent assay (DAS-ELISA). Purified anti-CMV-Y, -PRSV-W, -WMV 2 and -ZYMV $\gamma$-globulin and $\gamma$-globulin conjugated to alkaline phosphatase used in the experiment were provided by Dr. N. Sako of Saga University, Japan. The protocol of ELISA was as outlined by Clark and Adams ${ }^{6)}$ with slight modifications.

Table 1. List of the cucurbit-samples collected in Bangladesh

\begin{tabular}{rlll}
\hline No. & Plant samples & Symptoms & Location \\
\hline 1. & Bottlegourd & Mosaic & Nurbag, Gazipur \\
2. & Bottlegourd & Vein-clearing & Mouchak, Gazipur \\
3. & Bottlegourd & Mosaic & Gazipur, Gazipur \\
4. & Bottlegourd & Mosaic & Kashimpur, Gazipur \\
5. & Bottlegourd & Mosaic & Kashimpur, Gazipur \\
6. & Bottlegourd & Mosaic & Kashimpur, Gazipur \\
7. & Bottlegourd & Yellowing & Kashimpur, Gazipur \\
8. & Bittergourd & Mosaic, Curl & Joydebpur, Gazipur \\
9. & Bittergourd & Mosaic & Kashimpur, Gazipur \\
10. & Cucumber & Mosaic & Kashimpur, Gazipur \\
11. & Cucumber & Mosaic & Kashimpur, Gazipur \\
12. & Cucumber & Mosaic & Kashimpur, Gazipur \\
13. & Cucumber & Mosaic & Jessore, Jessore \\
14. & Round cucumber & Mosaic & Joydebpur, Gazipur \\
15. & Pumpkin & Mosaic & Kashimpur, Gazipur \\
16. & Pumpkin & Mosaic & Jessore, Jessore \\
17. & Pumpkin & Mosaic & Salna, Gazipur \\
18. & Spongegourd & Mosaic, Vein-clearing & Charpolisha, Jamalpur \\
19. & Sweetgourd & Mosaic & Katabari, Jamalpur \\
20. & Whitegourd & Mosaic & Kashimpur, Jamalpur \\
21. & Zucchini & Mosaic & Joydebpur, Gazipur \\
\hline
\end{tabular}


Wells of microtiter plate (Nunc, Denmark) were coated with $\gamma$-globulin $(2 \mu \mathrm{g} / \mathrm{ml}, 200 \mu \mathrm{l} /$ well) in $0.05 \mathrm{M}$ carbonate buffer ( $\mathrm{pH} 9.6$ ) containing $0.02 \%$ sodium azide and incubated at $37^{\circ} \mathrm{C}$ for $3 \mathrm{hr}$. The small amount ( $c a .0 .05 \mathrm{~g}$ ) of dried samples was macerated with glass rod on Parafilm in a few drops of PBS $(0.02 \mathrm{M}$ phosphate buffer, $0.15 \mathrm{M} \mathrm{NaCl}, 0.02 \%$ sodium azide) containing $0.05 \%$ Tween 20 and $2 \%$ polyvinylpyrrolidone (PVP Av. Mol. Wt. 40,000). An amount of $30 \mu \mathrm{l}$ aliquot was poured in each well containing $120 \mu \mathrm{l}$ sample buffer (PBS-Tween-PVP) and incubated for $4^{\circ} \mathrm{C}$ for $24 \mathrm{hr}$. The enzyme conjugated $\gamma$-globulins were applied at 1:1,000 dilution in PBS-Tween-PVP with $2 \%$ bovine serum albumin (BSA). After adding conjugated $\gamma$ globulin $\left(100 \mu \mathrm{l} /\right.$ well), the plate was incubated for $37^{\circ} \mathrm{C}$ for $3 \mathrm{hr}$. In each well an amount of $100 \mu \mathrm{l}$ of substrate ( $p$-nitrophenylphosphate, $1 \mathrm{mg} / \mathrm{ml}$ ) in $10 \%$ diethanolamine containing 0.02 $\%$ sodium azide (pH 9.6) was applied and incubated for $1 \mathrm{hr}$ at $30^{\circ} \mathrm{C}$. The plant leaves infected with each virus were used as positive control. The reaction was stopped by adding $50 \mu \mathrm{l}$ of $3 \mathrm{~N} \mathrm{NaOH}$ per well. Unless otherwise stated, the microtiter plates were washed at least four times with PBS-Tween after each incubations. Absorbance values were measured by using an ELISA analyzer (Immuno Reader NJ-2000) at $405 \mathrm{~nm}$. The experiments were designed so that there was two observations for each sample per plate.

Dot-immunobinding assay (DIBA). In DIBA, polyclonal antisera of CMV-Y, PRSV-W, PRSV-P, WMV 2, ZYMV, CGMMV-Y, CGMMV-W and SqMV were used. DIBA was essentially performed as described by Hibi and Saito ${ }^{14}$ with some modifications. Nitrocellulose membrane (NCM, Bio-Rad) was dipped in distilled water for $10 \mathrm{~min}$ and dried on filter papers for $5 \mathrm{~min}$. They were then dotted with $2 \mu 1$ sample extracts prepared by homogenizing $c a .0 .05 \mathrm{~g}$ dried samples in $0.5 \mathrm{ml}$ TBS $(0.02 \mathrm{M}$ Tris- $\mathrm{HCl}, 0.5 \mathrm{M} \mathrm{NaCl}, \mathrm{pH} 7.5)$ and dried for $15 \mathrm{~min}$. The NCMs were incubated in blocking solution consisted of $2 \% \mathrm{BSA}, 2 \%$ Triton X-100 in TBS for $1 \mathrm{hr}$, then briefly washed with TBST (Tween 20 in TBS). Antiserum $(1: 4,000)$ diluted with $1 \%$ healthy leaf extract in TBST containing $0.2 \%$ BSA and $2 \%$ PVP (polyvinylpyrrolidone) was spotted on the NCM at the rate of $20 \mu \mathrm{l} /$ grid and incubated for $50 \mathrm{~min}$. The NCM was rinsed in TBST for three times with gentle shaking for $30 \mathrm{~min}$. Membranes were incubated for $1 \mathrm{hr}$ in conjugate solution prepared by diluting with antibody buffer $(1: 8,000)$ and washed in TBST as described previously. Finally, the NCM was reacted with color development solution for 30-60 min as recommended by Banttari and Goodwin ${ }^{2}$. The reaction was stopped by washing the NCM in distilled water and then air dried for visual observation and storage. Unless otherwise stated, the NCMs were incubated at room temperature and all the operations were performed in plastic box. The experiments were repeated at least twice to confirm the results.

\section{RESULTS}

\section{DAS-ELISA}

As shown in Table 2, three viruses viz., CMV, PRSV and WMV 2 were detected by DASELISA from different cucurbitaceous samples. Among these viruses, PRSV was detected from 9 samples, CMV from two cucumber samples (Sample No. 10 and 11) and WMV 2 from one pumpkin sample (Sample No. 15). None of the samples were reacted positively against ZYMV in ELISA. Although the dried samples stored for 2-3 years were used, viruses were successfully detected without any difficulties due to non-specific reactions in DAS-ELISA. The absorbance values less than 0.1 were regarded as negative in all cases.

\section{$D I B A$}

The results of DIBA are summarized in Table 2. In all PRSV, SqMV, CMV and WMV 2 were detected from 9, 3, 2 and 1 samples, respectively. The mixed infection of PRSV with SqMV was detected from two samples of cucumber and sweetgourd (Sample No. 13 and 19), while round cucumber (Sample No. 14) was found to be singly infected with SqMV. The positive reaction of DIBA was graded by the appearance of distinct pu rple red spot on the NCM. In 


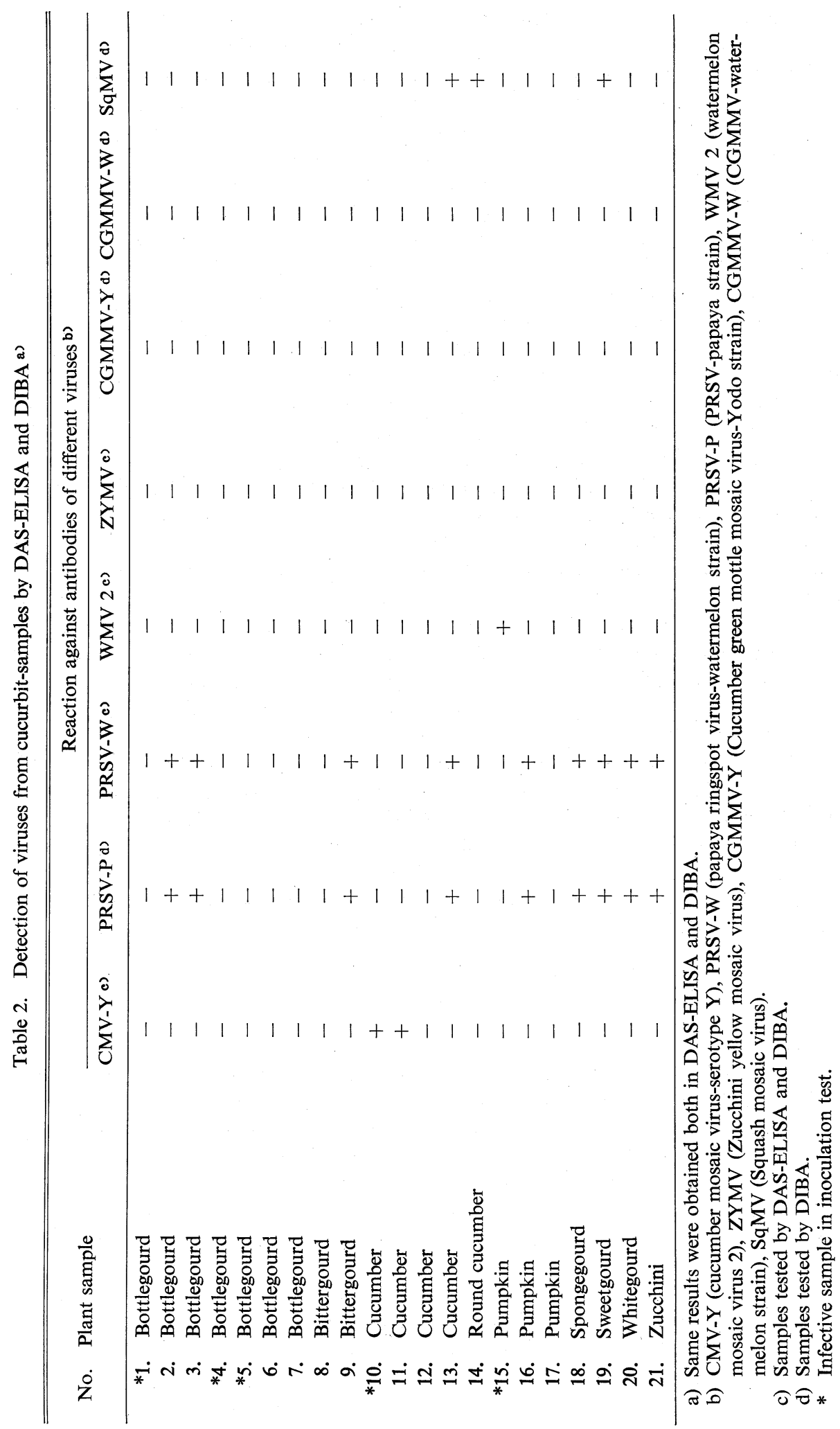


general, the appearance of non-specific reactions was regarded as the main problem of DIBA as reported by many researchers ${ }^{2,18,24,27)}$. The antisera used in this study was absorbed with the healthy leaf extracts of the propagation host plant for each virus antigen, and could successfully eliminate this problem.

\section{Inoculation test}

Five samples (marked with asterisk in Table 2) out of 21 were found to be infective in inoculation tests. Among these samples three bottlegourd samples (Sample No. 1, 4 and 5) produced mosaic symptoms on bottlegourd and cucumber plants. These isolates also induced nectoric local lesions to Gomphrena globosa and chlorotic local lesion on Chenopodium quinoa and $C$. amaranticolor. The three isolates produced identical symptoms on the inoculated plants. The cucumber sample (Sample No. 10) also produced similar type of yellow mosaic symptoms on cucumber. The necrotic local lesion on Pisum sativum and chlorotic local lesion on $C$. quinoa and $C$. amaranticolor were induced by the cucumber isolates. The only one sample of pumpkin (Sample No. 15) produced systemic mosaic symptoms on pumpkin and sweetgourd and also chlorotic local lesion on C. amaranticolor and C. quinoa.

\section{DISCUSSION}

The results of this study demonstrated that the cucurbitaceous crops in Bangladesh have been infected with CMV, PRSV, WMV 2, SqMV and one unidentified virus isolated from bottlegourd. Among these viruses PRSV was found to be common in nine different cucurbitaceous species tested and distributed to the all areas surveyed (Tables 1 and 2). WMV 2 with a wide host range which has been reported to cause severe damage to cucurbits in India ${ }^{31)}$ was detected only from one pumpkin sample. SqMV was detected from cucumber, round cucumber and sweetgourd samples of three different locations, though the virus was not reported from other tropical countries like India, Sri Lanka, Philippines and Thailand ${ }^{12,31)}$. PRSV-W and PRSV-P have been reported as serologically indistinguishable ${ }^{22)}$. Therefore, we could not identify the strains of PRSV distributed in Bangladesh whether they belong to PRSV-P or PRSV-W.

We failed to detect two important cucurbit-viruses, ZYMV and CGMMV from our samples. However, ZYMV has also been found to be absent in the list of virus diseases of crops in India, Sri Lanka, Philippines and Thailand ${ }^{12,30}$. So, this virus might not be present in Bangladesh and those tropical Asian countries. But the failure of detecting CGMMV from any samples is of interest as it has been reported to be quite common in India ${ }^{30)}$.

The viruses propagated from the cucumber (Sample No. 10) and pumpkin (Sample No. 15) were detected as CMV and WMV 2, respectively, by both DAS-ELISA and DIBA. The dip preparations of the leaves inoculated with three bottlegourd samples (Sample No. 1, 4 and 5) showed filamentous virus particles identical with the viruses of potyvirus group under the electron microscope. But they were found to be serologically unrelated to all the viruses tested. Further experiments on the other properties of the virus are necessary for identification. Another important aspect of inoculation test is that the viruses in most of the samples were found to be inactivated within 2-3 years storage. PRSV, the most common virus in Bangladesh seemed to be very unstable as all the samples were inactivated during preservation. The transportation of the samples from Bangladesh to Japan which changed the physical conditions of the samples for several days may be one of the reasons of loosing infectivity.

DAS-ELISA has been reported by many researchers as highly sensitive serological method over any other serological methods ${ }^{5,7,8}$. However, some researchers ${ }^{21,28)}$ reported that DIBA and DAS-ELISA were equal in sensitivity as serological methods. In our study, in which dried samples were used, both methods were found to be equally effective in detecting viruses. These informations suggest that serological methods are very useful to detect plant viruses distributed in an area or country more conveniently even after preservation for long time.

The number of samples used in this study were limited in respect to different cucurbitaceous 
species and collection sites. The kinds of anti-virus-sera used were also limited. Therefore, it is difficult to draw a sound conclusion on the virus diseases of cucurbitaceous crops in Bangladesh from this study. However, the results in our study revealed that four viruses serologically identical to PRSV, CMV, WMV 2 and SqMV are distributed on various cucurbitaceous crops in Bangladesh. Some other viruses including bottlegourd isolates which did not react with any antisera used also exist there. These facts emphasize the importance of taking in depth and well-planed research on the cucurbit-viruses in Bangladesh.

We are highly grateful to Dr. N. Sako, Saga University and Dr. T. Maeda, Okayama University, Japan for kindly providing antisera and technical advice throughout the experiments. Our sincere appreciations are also to Dr. M. Kameya, National Agriculture Research Center, Tsukuba, Japan and Dr. D. Gonsalves, Cornell University, USA, for generously supplying antisera. We are thankful to Dr. T. Kawarabata, Faculty of Agriculture, Kyushu University to provide the laboratory facilities for measuring ELISA values. Our appreciation extends to Dr. S.H. Khan, Director and Dr. I.H. Mian, Associate Professor of IPSA, Bangladesh for their cooperation during sample collection in Bangladesh. We also appreciate the support of JICA (Japan International Cooperation Agency)/IPSA (Instutite of PostGraduate Studies of Agriculture) Project, Bangladesh in this research.

\section{Literature cited}

1. Ahmed, K.M. (1984). Diseases of vegetables and fruit plants. First Biennial Conference (held on December 13-14) of Bangladesh Phytopathol. Soc., Bangladesh. p. 18.

2. Banttari, E.E. and Goodwin, P.H. (1985). Detection of potato virus $S, X$ and $Y$ by enzyme-linked immunosorbent assay on nitrocellulose membrane (DOT-ELISA). Plant Dis. 69: 202-205.

3. Campbell, R.N. (1971). Squash mosaic virus. CMI/AAB Descriptions of Plant Viruses No. 43.

4. Chala, V.P., Harrison, C.W. and Halliwell, R.S. (1987). Identification of two distinct strains of water melon mosaic virus 2 affecting cucurbits in Texas. Plant Dis. 71: 750-752.

5. Clark, M.F. (1981). Immunosorbent assays in plant pathology. Ann. Rev. Phytopath. 19: 83-106.

6. Clark, M.F. and Adams, A.N. (1977). Characteristics of the microplate method of enzyme-linked immunosorbent assay for the detection of plant viruses. J. gen. Virol. 34: 475-483.

7. Clark, M.F. and Bar-Joseph, M. (1984). Enzyme immunosorbent assays in plant virology. In Methods in Virology, Vol. VII (Maramorosch, K. and Koprowski, H. eds.). Academic Press, New York, pp. 51-85.

8. Clement, D.L., Lister, R.M. and Foster, J.E. (1986). ELISA-based studies on the ecology and epidemiology of barley yellow dwarf virus in Indiana. Phytopathology 76: 86-92.

9. FAO (1988). Year Book (Production), Vol. 42. Food and Agriculture Organization of the United Nations, Rome.

10. FAO (1990). Quarterly bulletin of statistics, Vol, 3. Food and Agriculture Organization of the United Nations, Rome.

11. Francki, R.I.B., Mossop, D.W. and Hatta, T. (1979). Cucumber mosaic virus. CMI/AAB Descriptions of Plant Viruses No. 213.

12. Fujisawa, I. (1989). Occurrence of vegetable viruses in South Asian countries. Shokubutsu bōeki 43: 484-487 (in Japanese).

13. Gibbs, A.J. and Harrison, B.D. (1979). Plant virology-The principles. Edward Arnold, London.

14. Hibi, T. and Saito, Y. (1985). A dot immunobinding assay for the detection of tobacco mosaic virus in infected tissues. J. gen. Virol. 66: 1191-1194.

15. Hill, S.A. (1984). Methods in Plant Virology, Vol. 1. Blackwell Scientific Publications, Oxford, London.

16. Huang, C.H., Hseu, S.H. and Tsai, J.H. (1989). Purification, serology and properties of five zucchini yellow mosaic virus isolates. Plant Pathol. 38: 414-420.

17. Lisa, V. and Lecoq, H. (1984). Zucchini yellow mosaic virus. CMI/AAB Descriptions of Plant Viruses No. 282.

18. Lizarraga, C. and Fernandez-Northcote, E.N. (1989). Detection of potato virus $X$ and $Y$ in sap extracts by a modified enzyme-linked immunosorbent assay on nitrocellulose membranes (NCM- 
ELISA). Plant Dis. 73: 11-14.

19. Lovisolo, O. (1981). Virus and viroid diseases of cucurbits. Acta Hortic. 88: 33-90.

20. Ohtsu, Y., Sako, N. and Somowiyarjo, S. (1985). Zucchini yellow mosaic virus isolated from pumpkin in Miyako and Yaeyama islands, Okinawa, Japan. Ann. Phytopath. Soc. Japan 51: 234-237.

21. Ozyanara, F. and Sako, N. (1987). The detection of cucumber mosaic virus strains by enzymelinked immunosorbent and dot-immunobinding assays. Bull. Fac. Agr. Saga Univ. 62: 109-115.

22. Purcifull, D., Edwardson, J., Hiebert, E. and Gonsalves, D. (1984). Papaya ringspot virus. CMI/ AAB Descriptions of Plant Viruses No. 292.

23. Purcifull, D., Hiebert, E. and Edwardson, J. (1984). Watermelon mosaic virus 2. CMI/AAB Descriptions of Plant Viruses No. 293.

24. Powell, C.A. (1987). Detection of three plant viruses by dot-immunobinding assay. Phytopathology 77: 306-309.

25. Rabbani, A.K.M.G. ed. (1984). Year book of Agricultural Statistics of Bangladesh. Government of the People's Republic of Bangladesh, Dhaka, Bangladesh.

26. Rashid, M.M. (1976). Vegetables in Bangladesh (in Bengali). BARI, Joydebpur, Bangladesh.

27. Smith, F.D. and Banttari, E.E. (1987). Dot-ELISA on nitrocellulose membranes for detection of potato leafroll virus. Plant Dis. 71: 795-799.

28. Somowiyarjo, S., Sako, N. and Nonaka, F. (1989). Dot-immunobinding assay for zucchini yellow mosaic virus using polyclonal and monoclonal antibodies. Ann. Phytopath. Soc. Japan 55: 56-63.

29. Somowiyarjo, S. (1989). Serological studies on three cucurbitaceous potyviruses. Proc. Sympo. Kyushu Div. Phytopath. Soc. Japan pp. 1-24.

30. Tropical Agriculture Research Center (1977). Symposium on virus diseases of tropical crops. Trop. Agri. Res. Ser. No. 10. TARC, Tsukuba, Japan.

31. Varma, A. (1988). The Indian subcontinent. In The Plant Viruses, the Filamentous Plant Viruses. Vol. 4 (Milne, R.G. ed.). Prenum Press, New York and London. pp. 371-378.

32. Yamamoto, T. and Ishii, M. (1983). Aphid transmission from cucumber cultivers infected with watermelon mosaic virus and cucumber mosaic virus. Ann. Phytopath. Soc. Japan 43: 508-513.

33. Yora, K., Saito, Y., Doi, Y., Inoue, T. and Tomaru, K. (1983). In Shokubutsu Virus Jiten. Asakura Shoten, Tokyo.

\section{和 文 摘 要}

Abdul Mannan AKANDA・津野和宣・脇本 哲：バングラデシュ国に分布するウリ科作物からの 4 種植物 ウイルスの血清学的検出

バングラデシュ国内各地からウイルス性と思われる病徵を呈した 9 種のウリ科植物から罹病葉 21 試料を 採集し, 真空凍結乾燥あるいは塩化カルシウムを用いた乾葉法により乾燥し， $4^{\circ} \mathrm{C} て ゙$ 保存した。約 2 年間保 存後, 大部分の試料ではウイルスの感染性を認めることができなかったので, ウリ科植物に奇生性をもつ7 種のウイルスに対する 8 種の抗血清を供試し，これらの試料中のウイルスを double antibody sandwich enzyme-linked immunosorbent assay (DAS-ELISA) および dot-immunobinding assay (DIBA) とよって検 出した。その結果, zucchini yellow mosaic virus と cucumber green mottle mosaic virus は検出されなかっ たが, cucumber mosaic virus, papaya ringspot virus, watermelon mosaic virus 2 怙よび squash mosaic virus が，それぞれ 2,9,1 打よび 3 点の試料から検出され，papaya ringspot virus がバングラデシュ国のウ リ科植物にとくに広く分布するものと考兄られた。ニウガオ，ツルレイシキュウリ括よびカボチャの試料 のなかには，用いたいずれの抗血清とも反応しないるのが認められた。 